\title{
Brain Stem Ependymoma
}

National Cancer Institute

\section{Source}

National Cancer Institute. Brain Stem Ependymoma. NCI Thesaurus. Code C5098.

An ependymoma that arises from the brain stem. 